\title{
Emil Wohlwill, Galileo and His Battle for the Copernican System*
}

Galileo Galilei is one of the few figures in the history of science who has attracted the imagination even of laymen to the natural sciences. The battle of this great physicist against the domination of his church, a battle which he ultimately lost, manifests fundamental human interest that extends beyond the individual. Galileo pits the right of the thinking individual against the right of an institution that defends its claim to set norms for individual thinking because it posseses superhuman truths.

Thus it is understandable that the discussion about Galileo continues today and will probably continue on in the foreseeable future. Every year new books and essays appear about Galileo's life or specific aspects of his work; the field of Galileo historiography is expanding and gradually becoming intractable in scope for any individual scholar.

However, the field is divided into categories; it has a number of landmarks that can not be ignored. This applies in particular to the few works written with such expert knowledge and command of the material that they have become indispensable secondary sources for all subsequent Galileo research.

Among these fundamental works is Emil Wohlwill's magnum opus, his twovolume Galileo biography. Wohlwill labored on this book forty years with extraordinary energy, but was ultimately unable to complete it. He worked as a rigorous and self-critical historian, under conditions which certainly would have induced others to give up.

Only the rudiments of independent historiography of the natural sciences existed in the second half of the nineteenth century. There were neither special libraries, research institutes, nor professorial chairs at universities.

Not even Wohlwill could make a career of his "unfortunate inclination" (Emil Wohlwill to Hans Zahn, 22 November 1903) toward the history of the natural

* Translator's note: This article was first published as an introduction to Wohlwill 1969. We thank Hans-Werner Schütt and the Sändig Verlag, Wiesbaden, for the kind permission to republish it. The original contains the following information: "A comprehensive portrayal of the personality and the work of Emil Wohlwill is in preparation at the Institute for History of the Natural Sciences of the University of Hamburg (Schütt 1972); to this end a wealth of material of previously unpublished documents has been analyzed." The notes have been standardized. The list of references can be found in a bibliographical section at the end of the appendix. 
sciences, even though his background and disposition gave him all the capabilities for it.

Born in Seesen in 1835, he grew up in an atmosphere of intellectual freedom and high demands. Emil's role model was his father Immanuel, despite his early death. He was descended from the sector of Jewish educated bourgeoisie that after the emancipation of the Jews at the beginning of the century had gradually lost its connection to orthodox Judaism. After their bitter historical experience, they regarded intellectual freedom as the only goal in life worthy of human beings.

The son also knew how to defend his intellectual freedom in an often truly tough life struggle. He wavered long between history and the natural sciences, but finally chose chemistry, which he studied from 1855 in Heidelberg, Berlin and Göttingen. In 1860 he received his doctorate from Friedrich Wöhler with a dissertation, "On Isomorphic Mixtures of Selenic Acid Salts."

In Berlin the young student attended a lecture on the history of physics by Johann Christian Poggendorff. As he later declared, his interest in the history of science was already awakening as an inner opprobrium of the dilettantism that accepted fables and legends so uncritically, a phenomenon he found prominent in large sectors of the historiography of his time (Wohlwhill to Hans Zahn, 22 November 1903). Ad fontes remained the guiding principle of his activity, and by holding on to this motto he became an expert scholar, even though in his isolation he easily could have become a dilettante himself.

The Hamburg of the $1860 \mathrm{~s}$, where Wohlwill settled after his studies, offered no opportunity for a personal exchange of scientific ideas. In any case, the young chemist initially was left with little time for his own research. For a time he pursued three occupations simultaneously: he was a commercial chemist, a physics teacher, and an industrial chemist at the Norddeutsche Affinerie. This non-ferrous metal foundry, one of the world's largest producers of pure copper, benefits even today from the pioneering achievements of its former employee Emil Wohlwill, who brought the electrolysis of non-ferrous metals to technical maturity.

In spite of his isolation and even though he achieved success in his work in other fields, Wohlwill remained true to the history of science. He never expressed his views about why he made Galileo research the most important object of his scientific work, but two reasons appear to be decisive. First of all, Wohwill must have sensed a spiritual relationship to the man who had to struggle for the freedom of his spirit. Secondly, only in Wohlwill's day had it really become possible to access the most important primary sources relating to the Galileo case. The secret files of the Inquisition on Galileo, which Napoleon had brought to Paris, were back in the possession of the Vatican since 1841 (not 1845, as often mistakenly believed) and made accessible for scientific research, initially in part, and later in full (Laemmel 1928, 406-07).

Years of study dedicated to these and other sources - in 1891 in the Vatican itself - made Emil Wohlwill the most important Galileo expert of the late nineteenth century along with the editor of the Edizione Nazionale, Antonio 
Favaro. As of any historical personality, every period must sketch its own picture of Galileo, but to do this adequately, to find its own perspective, it must know what the other pictures looked like. For the contemporary reader it is of absolutely no disadvantage to see that period - the late nineteenth century - shimmering through the lines of Wohlwill's biography of Galileo.

Wohlwill saw the history of the natural sciences as part of the history of culture. He once wrote, "We take pains for the history of science because from this historical study we may hope for revelation about the nature of all human thought, about the most internal nature of progress in all human development. By following the development of the natural sciences through the centuries, we engage in anthropology, the study of humans in the highest sense of the word" (Wohlwill 1867 , Lecture I, 3). These words express a faith in fundamental progress for the entire history of mankind. The history of the natural sciences merely offers the special advantage of being able to recognize and distinctly analyze this progress. The belief in progress, however, forces a certain polarity onto history, since progress, although ultimately accepted, always faces initial opposition from forces that try to obstruct it.

In the Galileo affair, "modern" physics represents the stimulating force; thus the "unmodern" physics of the Peripatetics and the Catholic Church, with its claim to primacy over physics, actually become obstructive forces.

It appears to us today that the contours of this picture are drawn somewhat too sharply. For instance, the Catholic Church and its special - also internal problems seem today more differentiated than Wohlwill portrayed them. He was thoroughly successful in showing the contradictory aspects of the behavior of the church authorities, but his suspicion that the Roman Inquisition committed crude forgery has not been confirmed (Laemmel 1928, 415). Some indications suggest, however, that during the trial of 1633 there was intent to deceive certain persons. This argues in favor of a very differentiated picture of the Catholic Church, as these persons must have been high church dignitaries themselves.

On the other hand, Wohlwill aptly described Galileo's character and difficult personal situation. The sections about the theory of tides, especially, show that Wohlwill possessed extraordinary sensitivity and empathy for the thought processes of the great physicist.

Two years before his death in 1912 and shortly after the publication of the first volume of his Galileo biography, Wohlwill expressed hope for the book's impact, "that one time or another a young person will discover that something is contained in it which he can use, and in his own interest must use" (Emil Wohlwill to Fritz Wohlwill, 12 August 1910). In view of the echo which his work has found, one can certainly say that this hope was not unjustified.

Institut für Philosophie, Wissenschaftstheorie, Wissenschafts- und Technikgeschichte Technische Universität Berlin 